\title{
Urban nature as a source of resilience during social distancing amidst the coronavirus pandemic
}

\author{
Karl Samuelsson 1,*, Stephan Barthel ${ }^{2,3}$, Johan Colding ${ }^{2,4}$, \\ Gloria Macassa ${ }^{5,6}$, Matteo Giusti ${ }^{2}$ \\ 1 Department of Geospatial and Computer Sciences, University of Gävle, Kungsbäcksvägen 47, 80 I \\ 76 Gävle, Sweden, ${ }^{2}$ Department of Building Engineering, Energy Systems and Sustainability Science, \\ University of Gävle, Sweden, ${ }^{3}$ Stockholm Resilience Centre, Stockholm University, Sweden, ${ }^{4}$ Beijer \\ Institute of Ecological Economics, Royal Swedish Academy of Sciences, Sweden, ${ }^{5}$ Department of \\ Public Health and Sports Science, University of Gävle, Sweden, ${ }^{6}$ EPIUnit - Instituto de Saúde \\ Pública, Universidade do Porto, Portugal \\ *Correspondence: karl.samuelsson@hig.se
}

The 2020 coronavirus pandemic caused countries across the world to implement measures of social distancing to curb spreading of COVID-19. The large and sudden disruptions to everyday life that result from this are likely to impact well-being, particularly among urban populations that live in dense settings with limited public space. In this paper, we argue that during these extraordinary circumstances, urban nature offers resilience for maintaining well-being in urban populations, while enabling social distancing. We discuss more generally the critical role of urban nature in times of crisis. Cities around the world need to take the step into the 2 Ist century by accepting crises as a new reality and finding ways to function during these disturbances. Thus, maintaining or increasing space for nature in cities and keeping it accessible to the public should be part of the sustainability agenda, aiming simultaneously to strive towards SDG 3 (good health and well-being), and SDG II (sustainable and resilient cities).

\section{Introduction}

The 2020 novel coronavirus pandemic has caused countries across the world to implement unprecedented measures of social distancing to curb spreading of COVID-19. Such measures include school closures and urging people to stay home, and centre around reducing the number of close physical interactions among people. It is widely regarded as one of the most effective approaches to keep COVID-19 cases down (Gu, Jiang, Zhao, \& Zheng, 2020; Tian et al., 2020; Wilder-Smith \& Freedman, 2020). Social distancing has simultaneously disrupted the everyday lives of entire populations wherever it has been implemented (Caria et al., 2020). Such large and sudden disruptions to everyday life are likely to impact human well-being, particularly so among populations that live in dense urban settings with limited public space. Elders, for example, that are at most risk of suffering with lethal effects from COVID-19 are a risk group by also suffering from anxiety and depression from social isolation (Hawkley \& Cacioppo, 2007; National Academies of Sciences Engineering and Medicine, 2020).

During these extraordinary circumstances of social distancing, urban nature offers resilience for maintaining well-being. The gist of this proposition is that in circumstances of voluntary social distancing, in which people are still allowed to visit outdoor environments, urban nature can provide people with opportunities to escape household confinement and enjoy a host of positive well-being effects (Hartig, Mitchell, de Vries, \& Frumkin, 2014; Markevych et al., 2017), and maintain social relationships even with due distance (Jennings $\&$ Bamkole, 2019) and provide a sense of connection with the outside world (Weimann, Björk, \& Håkansson, 2019). In this paper we examine some early indications around shifts in 
movement patters in cities during social distancing, and argue that ensuring nature access for the public should be a fundamental strategy of cities when coping with crisis, as is evident in the current situation and informed by the memory of historical insights.

\section{Access to natural habitats can help maintaining well-being in times of social distancing}

Global migration patterns will continue with an inflow of people into urban centres (UNHabitat, 2016). The compact-city model with high population density is often upheld as a desirable way of sustaining cities because it can mitigate climate change impacts due to a reduction of transportation and building energy use (Güneralp et al., 2017; Kennedy et al., 2015; Pan et al., 2019). Yet, it is increasingly criticised for not taking into account aspects of human well-being for the residents living in dense conglomerations, such as the lack of health-promoting environments like public parks and other forms of natural habitats (Gren, Colding, Berghauser-Pont, \& Marcus, 2018; Hartig \& Kahn, 2016; Kabisch, van den Bosch, \& Lafortezza, 2017; Samuelsson et al., 2018). During the current COVID-19 pandemic dense urban conglomerations function as epicentres for the spread of the coronavirus, as human interaction is high in these settings. Hence, to avoid spread of virus, authorities world-wide have prescribed social distancing that ranges from isolation among people in entire metropolitan areas and commanding inhabitants to stay home (shelter in place), to the closing down of meeting places and schools, and voluntary isolation of elders and other vulnerable sub-groups. While these measures can be effective against disease transmission (Gu et al., 2020; Tian et al., 2020; Wilder-Smith \& Freedman, 2020), they also often result in social isolation for many people. Social isolation can induce feelings of loneliness, with negative well-being consequences (Hawkley \& Cacioppo, 2010), such as increased risks of anxiety (Cacioppo et al., 2006), depression (Cacioppo, Hawkley, \& Thisted, 2010) and premature mortality (Holt-Lunstad, Smith, Baker, Harris, \& Stephenson, 2015). A recent review by Brooks et al. (2020) suggests that isolation due to social distancing from the COVID-19 pandemic could promote post-traumatic stress symptoms, confusion, and anger. It is an irony of fate that this pandemic has arrived at a time when more people than ever are living in single-person households (Ortiz-Ospina, 2019). Especially older people, which is the group most encouraged to keep social distance, also are most vulnerable to isolation impacts (Hawkley \& Cacioppo, 2007; National Academies of Sciences Engineering and Medicine, 2020). Ageing populations is a key demographic trend in many parts of the world (United Nations - Department of Economic and Social Affairs Population Division, 2015). Sheltering in place with family members also poses risks to well-being due to a drastic increase in domestic violence in many countries during the COVID-19 crisis (WHO, 2020a).

What kind of alternatives for healthy daily mobility habits exist for urban residents in situations when people need to observe social distance? As recent data indicates, access to nature seems to be even more important during the current situation of social distancing than previously before (e.g. Google 2020a). This is due to that urban nature provides a refuge and escape from household confinement. Absence of stressors of physical confinement combined with positively contributing factors of natural environments likely help to momentarily reduce stress and provide relaxation (Hartig et al., 2014; Tyrväinen et al., 2014). The benefits of nature interaction as doses of stress reduction are nowadays well-established in the literature (Barton \& Pretty, 2010; Cox et al., 2017). Hence, access to urban nature is especially important when stress levels are high in populations that suddenly are asked to shelter in place and that experience anxiety due to uncertainty and fear of infection (Brooks et al., 2020). 
Moreover, urban nature nurtures interactions not only with other peers but also with the natural world. Suffice to say, social relationships are maintained even with due to social distancing. Spending time with others in nature can build social capital and also improve social cohesion (Jennings \& Bamkole, 2019), critically needed during psychologically hardships. Contact with nature can also provide urban residents with a sense of coherence (Weimann et al., 2019), fulfilling evolutionary predispositions for biophilic connections (Kellert \& Wilson, 1993). Sense of coherence helps individuals to deal with and counteract stressors of everyday life (Antonovsky, 1996).

Access to nature furthermore helps people to stay physically healthy (Hartig et al., 2014; Markevych et al., 2017). Physical activity in nature (e.g. walking, cycling, gardening and other outdoor activities) can lower anxiety (Lawton, Brymer, Clough, \& Denovan, 2017) and reduce post-traumatic symptoms (Oppizzi \& Umberger, 2018), which might show to be important after the COVID-19 world-wide social distancing orders are liberalized (cf. Brooks et al., 2020).

Overall and in the context of the still unfolding COVID-19 pandemic, stress and anxiety arising from household confinement conflicts (e.g. domestic violence) as well as a pandemic induced economic recession that often results in involuntary job and income losses could turn into a full-fledged mental health crisis (Lu Dong \& Bouey, 2020; WHO, 2020b). While it would be quite impertinent to suggest that urban residents' contact with urban nature could completely combat the above challenges, we consider nature contact to be an important strategy to reconcile from various crises that result from social distancing in cities.

\section{Current indications and remaining questions around urban nature and social distancing}

We are already witnessing effects of social distancing in urban populations' use of urban space. During March 2020, Google (2020a) presented data of the magnitude of social distancing in different parts of the world, compiling changes in movement volumes in six spatial categories (retail and recreation, grocery and pharmacy, parks, transit, workplaces and residential). These data show how movement volumes have decreased in all categories but the residential and this pattern is nearly uniform across Europe and North America.

Interestingly, Sweden that has introduced softer measures of social distancing in comparison to other countries, have seen a marked increase in movement volumes in public parks (Google, 2020b), lending credence to the proposition about the value of urban nature as highlighted in this paper. These data could be further explored through disaggregated cell phone record analysis of the sort that has moved city science forward in recent years (Lei Dong et al., 2020; Schläpfer et al., 2014; Schläpfer, Szell, Salat, Ratti, \& West, 2020). It will be crucial to understand not just the magnitude of the effect of social distancing, but also how it changes people's activity spaces, how movement patterns shift across the day's 24 hours and how socio-economic factors impact on such changes that likely influence freedom of choice related to movement.

A key issue in our view is to understand how different environments offer resilience for maintaining human well-being in novel disturbance regimes of the Anthropocene. Public participatory GIS (PPGIS) might be a method capable of capturing data for developing such a knowledge frontier. PPGIS is a method to involve the public in geographical mapping to uncover context-sensitive place-based information (Brown \& Kyttä, 2014). It has been widely utilised to uncover how urban places relate to different aspects of urban residents' well-being, including social sustainability (Kyttä, Broberg, Haybatollahi, \& Schmidt-Thomé, 2016), outdoor activities (Raymond, Gottwald, Kuoppa, \& Kyttä, 2016) and psychological restoration (Giusti \& Samuelsson, 2020). A caveat of PPGIS is that it is dependent on 


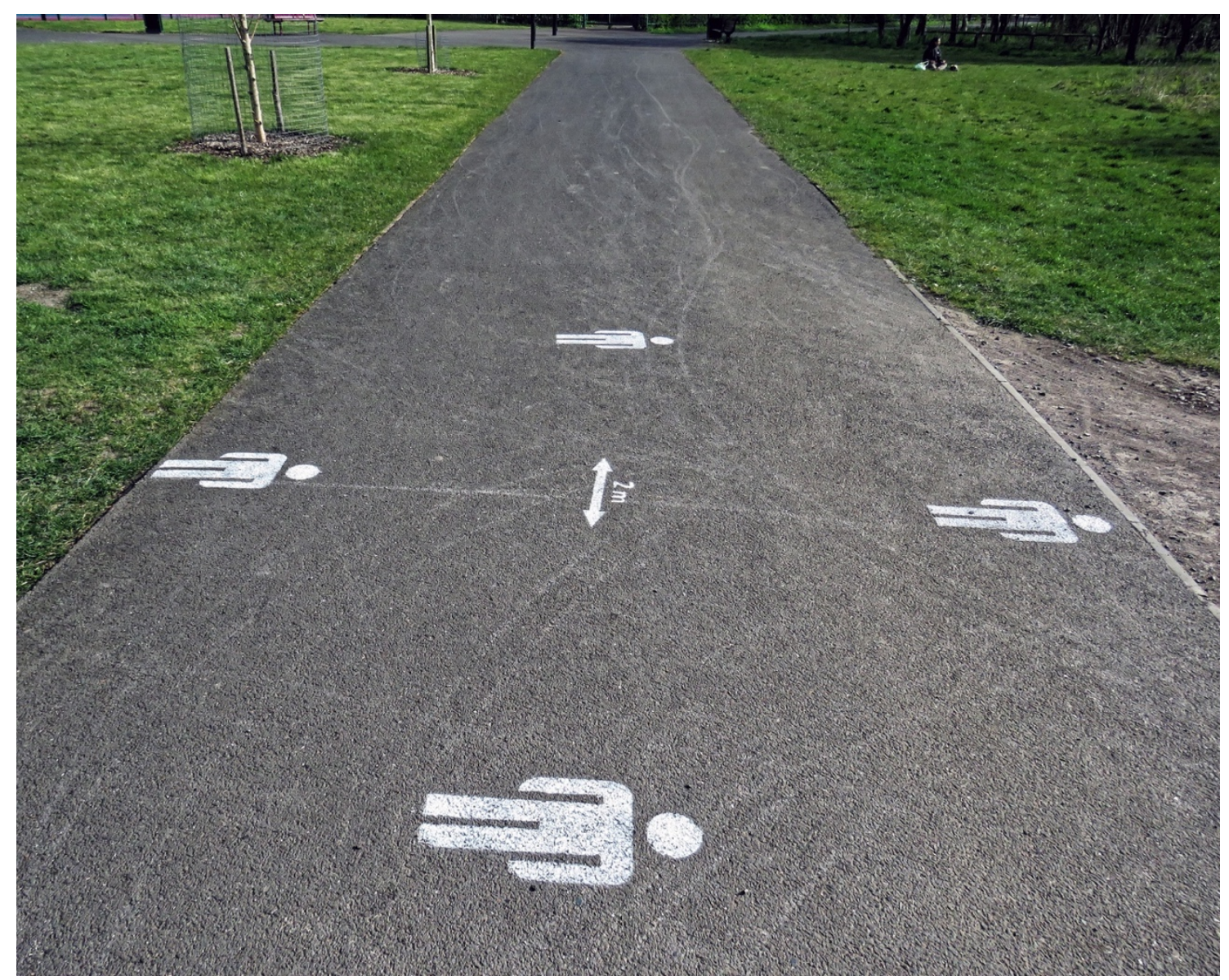

Figure I. Social distancing footpath markings in London, United Kingdom. By Acabashi under CC-BY-SA 4.0.

respondents' recollections of things. Due to the abrupt and large changes in urban mobility that social distancing involves, respondents would likely be able to provide reliable data for some time, but prospective PPGIS studies will benefit from as swift implementation as possible.

It is important to note that both cell phone records and PPGIS survey data risk being skewed towards younger segments of the population (Colding \& Barthel, 2017), while, as previously pointed out, the older demographic is of importance both with respect to COVID19 fears and vulnerability towards social isolation (National Academies of Sciences Engineering and Medicine, 2020). We thus want to highlight complementary approaches that can provide more nuanced understandings of elders' experiences, for example face-to-face interviews in the aftermath of the pandemic or phone interviews while it is currently ongoing.

\section{Increasing general resilience to future unknown crises on cities}

21 st century humanity will increasingly be urban (United Nations, 2014) and will increasingly face crisis and uncertainty (Biggs, Biggs, Dakos, Scholes, \& Schoon, 2011). The likelihood of new pandemic outbreaks is constantly on the rise, partly because humanity is continuing to urbanise (Madhav et al., 2017). Meanwhile, climate change will have urban populations increasingly face heat waves (Huang, Li, Liu, \& Seto, 2019) and flooding (Kulp \& Strauss, 2019). Despite much knowledge around the knock-on effects of the coronavirus pandemic remaining to be revealed, we already discern a lesson from watching the response to it: cities around the world need to take the step into the 21 st century by accepting new crises regimes of the Anthropocene as a new reality and finding ways to function during 
them. We want to highlight two complementary focal points that can be pivotal for dealing with crises in cities: spatial organisation and property rights arrangements.

Whether cities can simultaneously promote nature contact and social distancing is a matter of how they are spatially organised. Spatially contained development is advocated in order to decrease urban metabolism and mitigate climate change (Güneralp et al., 2017; Kennedy et al., 2015; Pan et al., 2019). However, plenty of space in cities needs also be allocated to nature for the sake of residents' well-being (Giusti \& Samuelsson, 2020; Hartig \& Kahn, 2016). These perhaps seemingly conflicting goals could be pursued by while spatially containing development also avoiding extreme densities, over-connected street networks and monofunctional neighbourhoods, thus providing access to both integrated spaces of social interaction and secluded restorative environments (Samuelsson, Colding, \& Barthel, 2019). Such diversity also entails possibilities for residents to easier shift their spatial habits to feature more nature environments in crisis times. Urban nature that is easy to access for residents provide more health benefits (Ekkel \& de Vries, 2017) and is more valued and appreciated (Hand et al., 2017). Conversely, it is noteworthy that the kind of spatially overconnected and normally crowded environments that are hampering well-being in non-crisis times (Samuelsson et al., 2019) also seem unfit to deliver benefits to urban populations during social distancing.

But while spatial organisation is crucial for achieving social distancing of the kind we are after in this paper, property-rights arrangements are equally important to consider. The right to access and make use of health-promoting environments is ultimately contingent upon property rights (Schlager \& Ostrom, 1992). Whether land in cities is held as private, public, or common ownership, is pivotal, since it determines opportunities for social distancing for urban residents, especially people living in densely built neighbourhoods. Nevertheless, whether people have the right to enjoy benefits of nature interaction tends seldom to be part of the urban sustainability agenda (Colding \& Barthel, 2013; Colding et al., 2013). Unfortunately, we are witnessing a global demise of public space. Public space represents the space which is "owned by the government, accessible to everyone without restriction, and/or fosters communication and interaction" (Kohn, 2004:9). While the actual production of public space has traditionally involved private actors, the government has generally been perceived as being in charge (Leclercq, Pojani, \& Van Bueren, 2020). However, urban neoliberal policies has resulted in a global surge in privatization of public space (Leclercq et al., 2020; Lee \& Webster, 2006). This includes public parks that in many parts of the world have been opened up to private business-interests, turning former park lands into cafés and other social spaces. While revenues from rents and property taxes make park restoration and management feasible, it occurs at the expense of public green space (Colding, 2011).

New York City, which was the first major epicentre of the US coronavirus outbreak, is a telling example of a city that is losing public space at a grand scale. With increasing fear of terrorism after 9/11, many places where people formerly could relax from stress and annoyance have been eradicated (Low, 2006). Not only has an increased fear of terrorism acted as a vindication for imposing restrictions on the use of public sidewalks and plazas, but also in the use of natural habitats, such as pocket parks (ibid.). During the current pandemic, the lack of public space in New York City has prompted banning cars on certain streets in order to provide more space for pedestrians (Ly, 2020).

In light of the current coronavirus pandemic, the authors behind this paper believe that cities can learn from history for how to better prepare for crisis. Nature areas in cities have repeatedly played a critical insurance role in times of crisis (Barthel et al., 2019; Colding \& Barthel, 2013). Community gardens in the United States have been widely recognized as an effective grassroots response to urban disinvestment and decay and have been used to 
promote economic development in many cities (Colding \& Barthel, 2013). Detroit is a telling example where community gardens have been used to supplement unemployed workers and their families with food (Warner, 1987) and create new jobs during economic recessions (Bonfiglio, 2009). Such responses to crisis are possible because there is open land for nature in the city that people have access to (Barthel, Parker, \& Ernstson, 2015). During the current pandemic, social distancing has so far been the imperative concern for most cities, but a looming threat that might follow in the wake of pandemics are cuts in food supply chains. Such potential disturbance creates a need for greater local food production capacities inside metropolitan landscapes (Barthel et al., 2019). Despite seemingly divergent ideologies, previously Havana (ibid.), and now also Singapore (Tan, 2020) are examples of cities that have prepared for cuts in supply lines. This illustrates how resilience building practices drawing on nature based solutions become critical to nurture and keep alive in collective memory during times of economic expansion and social prosperity (Colding \& Barthel, 2013; Kabisch et al., 2017; McPhearson, Andersson, Elmqvist, \& Frantzeskaki, 2015). Thus, keeping or increasing space for nature in cities and keeping it accessible to the public has to be part of sustainability policy aiming simultaneously to strive towards SDG 3 (good health and well-being), and SDG 11 (sustainable and resilient cities).

\section{Conclusion}

The coronavirus pandemic entails unchartered territory for many research fields beyond the medical ones. The response of massive social distancing constitutes a natural experiment around human-human and human-environment interactions without comparison in history. This novel situation especially puts light on an urgently needed knowledge frontier drawing on resilience science, city science and public health studies.

Early signals show that in Sweden, where soft measures centred around appeals to social distancing have been implemented rather than strict rules, people have turned to urban nature (Arslanovic \& Flygt, 2020; Google, 2020b). This is not surprising to us, because nature contact can provide a host of positive well-being effects while still allowing for social distancing. These indications rather highlight that access to urban nature is important for urban resilience in the short- and long-term. In the short-term, it provides much-needed buffering capacity during the ongoing pandemic for maintaining mental and physical health, social relationships and communion with the natural world. At the same time, how space and property rights are arranged to ensure access to urban nature will be of direct importance for building general urban resilience in the long-term.

We do not know what changes to people's everyday life will ensue in the wake of the coronavirus pandemic. Yet, given its global extension and the current lack of a vaccine, it is unlikely that societies and people will resume pre-COVID-19 lifestyles in a business-as-usual fashion. A more fit development would be one of accepting the new crises regime of the Anthropocene that is likely to unfold and hit civilization in various ways down the line.

\section{References}

Antonovsky, A. (1996). The salutogenic model as a theory to guide health promotion 1. Health Promotion International, 11(1), 11-18. https://doi.org/10.1093/heapro/11.1.11

Arslanovic, A., \& Flygt, M. (2020). Skogen - en tillflyktsort för många i virustider. Retrieved April 6, 2020, from https://www.svt.se/nyheter/lokalt/sodertalje/skogenblir-en-undanflykt-for-manga-i-virustider

Barthel, S., Isendahl, C., Vis, B. N., Drescher, A., Evans, D. L., \& van Timmeren, A. (2019). Global urbanization and food production in direct competition for land:
Leverage places to mitigate impacts on SDG2 and on the Earth System. The Anthropocene Review, (June), 205301961985667.

https://doi.org/10.1177/2053019619856672

Barthel, S., Parker, J., \& Ernstson, H. (2015). Food and Green Space in Cities: A Resilience Lens on Gardens and Urban Environmental Movements. Urban Studies, 52(May), 1321-1338. https://doi.org/10.1177/0042098012472744

Barton, J., \& Pretty, J. (2010). What is the best dose of nature and green exercise for improving mental 
health- A multi-study analysis. Environmental Science and Technology, 44(10), 3947-3955. https://doi.org/10.1021/es903183r

Biggs, D., Biggs, R., Dakos, V., Scholes, R. J., \& Schoon, M. (2011). Are we entering an era of concatenated global crises? Ecology and Society, 16(2). https://doi.org/10.5751/ES-04079-160227

Bonfiglio, O. (2009). Delicious Detroit. The city is plowing resources into its extensive vacant land. The Magazine of the American Planning Association, 3237.

Brooks, S. K., Webster, R. K., Smith, L. E., Woodland, L., Wessely, S., Greenberg, N., \& Rubin, G. J. (2020). The psychological impact of quarantine and how to reduce it: rapid review of the evidence. The Lancet, 395(10227), 912-920. https://doi.org/10.1016/S01406736(20)30460-8

Brown, G., \& Kyttä, M. (2014). Key issues and research priorities for public participation GIS (PPGIS): A synthesis based on empirical research. Applied Geography, 46, 126-136.

https://doi.org/10.1016/j.apgeog.2013.11.004

Cacioppo, J. T., Hawkley, L. C., Ernst, J. M., Burleson, M., Berntson, G. G., Nouriani, B., \& Spiegel, D. (2006). Loneliness within a nomological net: An evolutionary perspective. Journal of Research in Personality, 40(6), 1054-1085. https://doi.org/10.1016/j.jrp.2005.11.007

Cacioppo, J. T., Hawkley, L. C., \& Thisted, R. A. (2010). Perceived social isolation makes me sad: 5-year cross-lagged analyses of loneliness and depressive symptomatology in the chicago health, aging, and social relations study. Psychology and Aging, 25(2), 453-463. https://doi.org/10.1037/a0017216

Caria, S., Fetzer, T., Fiorin, S., Goetz, F., Gomez, M., Haushofer, J., ... Yoeli, E. (2020). Measuring Worldwide COVID-19 Attitudes and Beliefs. Retrieved April 9, 2020, from https://osf.io/3sn2k/

Colding, J. (2011). Creating incentives for increased public engagement in ecosystem management through urban commons. In Adapting Institutions: Governance, Complexity and Social-Ecological Resilience (pp. 101-124). Cambridge, UK: Cambridge University Press.

Colding, J., \& Barthel, S. (2013). The potential of "Urban Green Commons" in the resilience building of cities. Ecological Economics, 86, 156-166. https://doi.org/10.1016/j.ecolecon.2012.10.016

Colding, J., \& Barthel, S. (2017). An urban ecology critique on the "Smart City" model. Journal of Cleaner Production, 164, 95-101. https://doi.org/10.1016/j.jclepro.2017.06.191

Colding, J., Barthel, S., Bendt, P., Snep, R., van der Knaap, W., \& Ernstson, H. (2013). Urban green commons: Insights on urban common property systems. Global Environmental Change, 23(5), 1039-1051. https://doi.org/10.1016/j.gloenvcha.2013.05.006

Cox, D. T. C., Shanahan, D. F., Hudson, H. L., Plummer, K. E., Siriwardena, G. M., Fuller, R. A., ... Gaston, K. J. (2017). Doses of Neighborhood Nature: The Benefits for Mental Health of Living with Nature. BioScience, 7(2), biw173. https://doi.org/10.1093/biosci/biw173

Dong, Lei, O'Keeffe, K., Santi, P., Vazifeh, M., Anklesaria, S., Schläpfer, M., ... Ratti, C. (2020). The spectral dimension of human mobility. Retrieved from http://arxiv.org/abs/2002.06740

Dong, Lu, \& Bouey, J. (2020). Public mental health crisis during COVID-19 pandemic, China. Emerging

Infectious Diseases, 26(7).

https://doi.org/10.3201/eid2607.200407

Ekkel, E. D., \& de Vries, S. (2017). Nearby green space and human health: Evaluating accessibility metrics. Landscape and Urban Planning, 157, 214-220. https://doi.org/10.1016/j.landurbplan.2016.06.008

Giusti, M., \& Samuelsson, K. (2020). The regenerative compatibility: A synergy between healthy ecosystems, environmental attitudes, and restorative experiences. PLoS ONE, 15(1), e0227311. https://doi.org/10.1371/journal.pone.0227311

Google. (2020a). COVID-19 Community Mobility Reports. Retrieved April 5, 2020, from https://www.google.com/covid19/mobility/

Google. (2020b). Sweden March 29, 2020 Mobility changes. Retrieved from https://www.google.com/covid19/mobility/

Gren, Å., Colding, J., Berghauser-Pont, M., \& Marcus, L. (2018). How smart is smart growth? Examining the environmental validation behind city compaction. Ambio. https://doi.org/10.1007/s13280-018-1087-y

Gu, C., Jiang, W., Zhao, T., \& Zheng, B. (2020). Mathematical recommendations to fight against COVID-19. Retrieved from http://dx.doi.org/10.2139/ssrn.3551006

Güneralp, B., Zhou, Y., Ürge-Vorsatz, D., Gupta, M., Yu, S., Patel, P. L., ... Seto, K. C. (2017). Global scenarios of urban density and its impacts on building energy use through 2050. Proceedings of the National Academy of Sciences, 114(34), 201606035. https://doi.org/10.1073/pnas.1606035114

Hand, K. L., Freeman, C., Seddon, P. J., Recio, M. R., Stein, A., \& Heezik, Y. Van. (2017). The importance of urban gardens in supporting children's biophilia. Proceedings of the National Academy of Sciences, 114(2), 274-279. https://doi.org/10.1073/pnas.1609588114

Hartig, T., \& Kahn, P. H. J. (2016). Living in cities, naturally. Science, 352(6288), 938-940. https://doi.org/10.1126/science.aaf3759

Hartig, T., Mitchell, R., de Vries, S., \& Frumkin, H. (2014). Nature and health. Annual Review of Public Health, 35(December 2013), 207-228. https://doi.org/10.1146/annurev-publhealth-032013182443

Hawkley, L. C., \& Cacioppo, J. T. (2007). Aging and loneliness: Downhill quickly? Current Directions in Psychological Science, 16(4), 187-191. https://doi.org/10.1111/j.1467-8721.2007.00501.x

Hawkley, L. C., \& Cacioppo, J. T. (2010). Loneliness matters: A theoretical and empirical review of consequences and mechanisms. Annals of Behavioral Medicine, 40(2), 218-227. https://doi.org/10.1007/s12160-010-9210-8

Holt-Lunstad, J., Smith, T. B., Baker, M., Harris, T., \& Stephenson, D. (2015). Loneliness and Social Isolation as Risk Factors for Mortality: A MetaAnalytic Review. Perspectives on Psychological Science, 10(2), 227-237. https://doi.org/10.1177/1745691614568352

Huang, K., Li, X., Liu, X., \& Seto, K. C. (2019). Projecting global urban land expansion and heat island intensification through 2050. Environmental Research Letters, 14(11), 114037. https://doi.org/10.1088/17489326/ab4b71

Jennings, V., \& Bamkole, O. (2019). The relationship 
between social cohesion and urban green space: An avenue for health promotion. International Journal of Environmental Research and Public Health, 16(3). https://doi.org/10.3390/ijerph16030452

Kabisch, N., van den Bosch, M., \& Lafortezza, R. (2017).

The health benefits of nature-based solutions to urbanization challenges for children and the elderly A systematic review. Environmental Research, 159(January), 362-373. https://doi.org/10.1016/j.envres.2017.08.004

Kellert, S. R., \& Wilson, E. O. (Eds.). (1993). The Biophilia Hypothesis. Washington, DC: Island Press.

Kennedy, C. A., Stewart, I., Facchini, A., Cersosimo, I., Mele, R., Chen, B., ... Sahin, A. D. (2015). Energy and material flows of megacities. Proceedings of the National Academy of Sciences of the United States of America, 112(19), 5985-5990. https://doi.org/10.1073/pnas.1504315112

Kohn, M. (2004). Brave New Neighborhoods. Abingdon: Routledge.

Kulp, S. A., \& Strauss, B. H. (2019). New elevation data triple estimates of global vulnerability to sea-level rise and coastal flooding. Nature Communications, 10(1). https://doi.org/10.1038/s41467-019-12808-z

Kyttä, M., Broberg, A., Haybatollahi, M., \& SchmidtThomé, K. (2016). Urban happiness: context-sensitive study of the social sustainability of urban settings. Environment and Planning B: Planning and Design, 43, 34-57. https://doi.org/10.1177/0265813515600121

Lawton, E., Brymer, E., Clough, P., \& Denovan, A. (2017). The relationship between the physical activity environment, nature relatedness, anxiety, and the psychological well-being benefits of regular exercisers. Frontiers in Psychology, 8(JUN). https://doi.org/10.3389/fpsyg.2017.01058

Leclercq, E., Pojani, D., \& Van Bueren, E. (2020). Is public space privatization always bad for the public? Mixed evidence from the United Kingdom. Cities, 100, 122. https://doi.org/10.1016/j.cities.2020.102649

Lee, S., \& Webster, C. (2006). Enclosure of the urban commons. GeoJournal, 66(1-2), 27-42. https://doi.org/10.1007/s10708-006-9014-3

Low, S. M. (2006). The Erosion of Public Space and the Public Realm: paranoia, surveillance and privatization in New York City. City, 18(1), 43-49. https://doi.org/10.1525/city.2006.18.1.43

Ly, L. (2020, March 24). New York City will close streets to create outdoor space for residents. Retrieved April 9, 2020, from https://edition.cnn.com/world/livenews/coronavirus-outbreak-03-24-20-intlhnk/h_63fe327135fea1de1219ae6428b7d547

Madhav, N., Oppenheim, B., Gallivan, M., Mulembakani, P., Rubin, E., \& Wolfe, N. (2017). Pandemics: Risks, Impacts, and Mitigation. In Disease Control Priorities, Third Edition (Volume 9): Improving Health and Reducing Poverty (pp. 157-166). Washington, DC: The World Bank Group. https://doi.org/10.1596/978-1-4648-0527-1_ch8

Markevych, I., Schoierer, J., Hartig, T., Chudnovsky, A., Hystad, P., Dzhambov, A. M., ... Fuertes, E. (2017). Exploring pathways linking greenspace to health: Theoretical and methodological guidance. Environmental Research, 158(June), 301-317. https://doi.org/10.1016/j.envres.2017.06.028

McPhearson, T., Andersson, E., Elmqvist, T., \& Frantzeskaki, N. (2015). Resilience of and through urban ecosystem services. Ecosystem Services, 12, $152-156$.

https://doi.org/10.1016/j.ecoser.2014.07.012

National Academies of Sciences Engineering and Medicine. (2020). Social Isolation and Loneliness in Older Adults: Opportunities for the Health Care System. https://doi.org/10.17226/25663

Oppizzi, L. M., \& Umberger, R. (2018). The Effect of Physical Activity on PTSD. Issues in Mental Health Nursing, 39(2), 179-187. https://doi.org/10.1080/01612840.2017.1391903

Ortiz-Ospina, E. (2019). The rise of living alone: how oneperson households are becoming increasingly common around the world. Retrieved April 9, 2020, from https://ourworldindata.org/living-alone

Pan, H., Page, J., Zhang, L., Cong, C., Ferreira, C., Jonsson, E., ... Kalantari, Z. (2019). Understanding interactions between urban development policies and GHG emissions: A case study in Stockholm Region. Ambio, (2016). https://doi.org/10.1007/s13280-01901290-y

Raymond, C. M., Gottwald, S., Kuoppa, J., \& Kyttä, M. (2016). Integrating multiple elements of environmental justice into urban blue space planning using public participation geographic information systems. Landscape and Urban Planning, 153, 198208. https://doi.org/10.1016/j.landurbplan.2016.05.005

Samuelsson, K., Colding, J., \& Barthel, S. (2019). Urban resilience at eye level: Spatial analysis of empirically defined experiential landscapes. Landscape and Urban Planning, 187(November 2018), 70-80. https://doi.org/10.1016/j.landurbplan.2019.03.015

Samuelsson, K., Giusti, M., Peterson, G. D., Legeby, A., Brandt, S. A., \& Barthel, S. (2018). Impact of environment on people's everyday experiences in Stockholm. Landscape and Urban Planning, 171, 717. https://doi.org/10.1016/j.landurbplan.2017.11.009

Schlager, E., \& Ostrom, E. (1992). Property-Rights Regimes and Natural Resources : A Conceptual Analysis Property-Rights Regimes and Natural Resources : A Conceptual Analysis Edella Schlager and Elinor Ostrom property rights and the rules used to create. Land Economics, 68(3), 249-262. https://doi.org/10.2307/3146375

Schläpfer, M., Bettencourt, L. M. A., Grauwin, S., Raschke, M., Claxton, R., Smoreda, Z., ... Ratti, C. (2014). The scaling of human interactions with city size. Journal of the Royal Society, Interface / the Royal Society, 11(98), 20130789https://doi.org/10.1098/rsif.2013.0789

Schläpfer, M., Szell, M., Salat, H., Ratti, C., \& West, G. B. (2020). The hidden universality of movement in cities, arXiv:2002.06070 [physics.soc-ph]. Retrieved from http://arxiv.org/abs/2002.06070

Tan, A. (2020, April 1). Coronavirus: Singapore made plans to ensure food security years ago, says DPM Heng. Retrieved April 9, 2020, from https://www.straitstimes.com/singapore/environment/ singapore-made-plans-to-ensure-food-security-yearsago-dpm-heng

Tian, H., Liu, Y., Li, Y., Wu, C.-H., Chen, B., Moritz, U. G. K., ... Dye, C. (2020). An investigation of transmission control measures during the first 50 days of the COVID-19 epidemic in China. Science, $10.1126 / s c, 1-13$. https://doi.org/10.1126/science.abb6105 
Tyrväinen, L., Ojala, A., Korpela, K., Lanki, T., Tsunetsugu, Y., \& Kagawa, T. (2014). The influence of urban green environments on stress relief measures: A field experiment. Journal of Environmental Psychology, 38, 1-9. https://doi.org/10.1016/j.jenvp.2013.12.005

UN-Habitat. (2016). World Cities Report 2016. Urbanization and Development: Emerging Futures. https://doi.org/10.1097/NCM.0000000000000166

United Nations. (2014). World Urbanization Prospects: The 2014 Revision, Highlights (ST/ESA/SER.A/352). https://doi.org/10.4054/DemRes.2005.12.9

United Nations - Department of Economic and Social Affairs Population Division. (2015). World Population Ageing Report. ST/ESA/SER.A/390.

Warner, S. B. (1987). To Dwell is to Garden: A History of Boston's Community Gardens. Boston: Northeastern University Press.

Weimann, H., Björk, J., \& Håkansson, C. (2019). Experiences of the urban green local environment as a factor for well-being among adults: An exploratory qualitative study in southern Sweden. International
Journal of Environmental Research and Public

Health, 16(14).

https://doi.org/10.3390/ijerph16142464

WHO. (2020a). COVID-19 and violence against women What the health sector / system can do. Retrieved from

https://www.who.int/reproductivehealth/publications/ vaw-covid-19/en/

WHO. (2020b). Mental health and psychological resilience during the COVID-19 pandemic. Retrieved April 3, 2020, from http://www.euro.who.int/en/healthtopics/health-emergencies/coronavirus-covid19/news/news/2020/3/mental-health-andpsychological-resilience-during-the-covid-19pandemic

Wilder-Smith, A., \& Freedman, D. O. (2020). Isolation, quarantine, social distancing and community containment: pivotal role for old-style public health measures in the novel coronavirus (2019-nCoV) outbreak. Journal of Travel Medicine, 1-4. https://doi.org/10.1093/jtm/taaa020 